\title{
Safety Evaluation of Stacked Genetically Modified Corn Event (MON89034 × MON88017) Using Zebrafish as an Animal Model
}

\author{
Ahmed M. Rayan ${ }^{*}$, Fikru Nigussie ${ }^{2}$, Louise C. Abbott ${ }^{2}$ \\ ${ }^{1}$ Food Technology Department, Faculty of Agriculture, Suez Canal University, Ismailia, Egypt \\ ${ }^{2}$ Veterinary Integrative Biosciences Department, College of Veterinary Medicine and Biomedical Sciences, \\ Texas A\&M University, College Station, USA \\ Email: *ammrayan@yahoo.com
}

Received 19 August 2015; accepted 26 October 2015; published 29 October 2015

Copyright (C) 2015 by authors and Scientific Research Publishing Inc.

This work is licensed under the Creative Commons Attribution International License (CC BY). http://creativecommons.org/licenses/by/4.0/

(c) (i) Open Access

\section{Abstract}

This study assessed the effect of feeding stacked genetically modified (GM) corn event (M0N89034 $\times$ MON88017) on embryonic development, adult tissue histology and assessed the possibility of transgenic DNA transfer, using zebrafish as an animal model. Adult zebrafish were separated into male and female groups. After 3 weeks of feeding with experimental diets, males and females were paired once a week and fertilized embryos were collected, then the male and female fish were returned to their sex-specific groups. This fertilization and embryo collection process were repeated 3 times. Embryonic morphological measurements were obtained on developing embryos up to 96 hours after fertilization, and then the embryos were fixed in $4 \%$ phosphate-buffered paraformaldehyde for morphologic assessment. At the end of the feeding study, various adult zebrafish tissues were histologically examined for abnormalities. Both zebrafish tissues and embryos were analyzed for presence of plant specific genes and transgenic sequences. No changes or abnormalities were observed in embryonic morphology nor in any of the tissues examined histologically. In addition, no plant DNA reference genes or transgenic DNA were found in any of the analyzed samples. These results demonstrate that the safety and nutrition of MON89034 × MON88017 corn are similar to non-GM corn.

\section{Keywords}

Embryonic Development, GM Corn, Safety Evaluation, Transgenic DNA, Zebrafish

\footnotetext{
${ }^{*}$ Corresponding author.
}

How to cite this paper: Rayan, A.M., Nigussie, F. and Abbott, L.C. (2015) Safety Evaluation of Stacked Genetically Modified Corn Event (MON89034 × MON88017) Using Zebrafish as an Animal Model. Food and Nutrition Sciences, 6, $1285-1295$. 


\section{Introduction}

With the worldwide commercialization and rapid increase in genetically modified organisms (GMOs), numerous transgenic crops are being developed with modified trait involving multiple genes for various characteristics with the expectation of solving problems such as disease, weed management and enhancing production efficiency as well as improving functional properties [1]. According to the definition provided by Organization for Economic Co-operation and Development (OECD), a "stacked GMO" can be a retransformation of an existing transgenic line or crossing between two or more existing GM transgenic lines [2].

In the European Union (EU), stacked GM events are assessed as new GMOs, although not all aspects of the safety assessment for single GM events are deemed to be as relevant for stacked GM events [3]. In the Commission Implementation Regulation (EU) No. 503/2013, which came into force in June 2013 [4], it is reported that stacked GM events need to be assessed in relation to: 1) stability of the inserts; 2) expression of the introduced genes and their gene products; and 3) potential synergistic or antagonistic effects. This also pertains to any subcombinations, in the case of a multiple stacked GM event, where the stacked GM event has not yet been authorized separately.

Considering the rapid increase in number of GM constructs, more efficient and faster methods are needed to determine whether feeds and food contain approved or unapproved GM ingredients. Genetically modified constructs are often composed of common elements such as the 35S promoter, the NOS terminator or an antibiotic resistance gene as selection markers [5]. If these elements are detected, GM material may be present [6]. Due to increased feeding of GM plants to meat, milk and egg producing animals, safety concerns have been raised with respect to potential adverse effects on animals and humans health [6]-[10]. GM plants directly consumed by human or the transfer of the recombinant DNA and proteins from diet to livestock and livestock derived products that are consumed by humans may pose a perceived or possibly even real development of toxicity leading to risk to human health [11].

Several studies have confirmed the compositional and nutritional equivalence of GM crops when compared with their isogenic non-GM or conventional counterparts [12]-[16]. Numerous animal studies have focused on evaluating the risks of feeding GM maize on health and growth parameters and no abnormalities have been identified [17]-[20]. However, other animal studies have indicated serious health risks associated with consumption of GM food [21]-[26].

In order to prove safety in the EU, GMOs must be subjected to toxicological tests, including animal feeding trials and risk assessment must be performed by the European Food Safety Authority (EFSA). That is, only organisms or products that are evaluated as safe by EFSA can be allowed to enter the market by the European Union Commission [27]. Within the context of agricultural biotechnology, the overall goal of the safety assessment is not to demonstrate that foods obtained from GM crops are absolutely safe, but rather to demonstrate that they are as safe as those obtained from non-GM comparators [28].

Zebrafish (Danio rerio) are a powerful vertebrate animal model system that can be used as an effective alternative to mammalian animal testing to study mechanisms of toxicity [29]. Using zebrafish as a model organism, duration and cost of trials can be greatly reduced. When working with GM feed ingredients, it is a challenge to obtain a proper control, such as the near-isogenic maternal line of the GM event. Thus, it is advantageous that only small amounts are required to conduct a feeding trial. Furthermore, fish performance and health are issues of economical and animal welfare concern in their own right, and fish health could be influenced by the newly expressed protein and/or unintended effects from the GM event [30].

Genuity VT Triple PRO (MON89034 $\times$ MON88017) is a genetically modified corn hybrid produced by crossing two GM maize inbreds: MON89034 and MON88017. This hybrid cross expresses cry1A.105 and cry2Ab2 genes (insect resistance: Lepidoptera) from MON89034, cry3Bb1 gene (insect resistance: Coleoptera) and cp4epsps gene (herbicide tolerance: glyphosate) from MON88017. The aim of this study was to determine the effect of feeding stacked genetically modified corn event (MON89034 $\times$ MON88017) on the embryonic development, adult histology and assess the possibility of transgenic DNA transfer to adult zebrafish tissues and embryos.

\section{Materials and Methods}

\subsection{Plant Material}

The genetically modified corn sample event (MON89034 $\times$ MON88017) was collected from field trials con- 
ducted in the United States (Texas A\&M Agrilife Research and Extension Center at Corpus Christi, South Texas, USA). Non-genetically modified (near isogenic) corn B73 $\times$ MO17 is a hybrid formed from the cross of two related non-transgenic inbreds, B73 and MO17, both of which lacked the transgenic elements found in the GM corn sample, was used as the control. The non-GM corn $(\mathrm{B} 73 \times \mathrm{MO17})$ was obtained from USDA-ARS-MWA, United States Department of Agriculture, USA. This line was cultivated and harvested under identical conditions in the same location at Texas, USA.

\subsection{Fish Husbandry and Sampling}

Adult fish were raised and kept under standard laboratory conditions at $28.5^{\circ} \mathrm{C}$ [31] in the Department of Biology at Texas A\&M University. Adults zebrafish were randomly divided into four groups (8 per group): Icontrol male group (given non-modified feed), II—control female group (given non-modified feed), IIIexperimental male group (given GM corn feed), and IV-experimental female group (given GM corn feed). After feeding zebrafish with control diet (containing 20\% non-GM corn) or the experimental diet (containing 20\% transgenic corn) for 3 weeks, male and female adult zebrafish were paired in the evening and fertilized embryos were obtained at 10 to $11 \mathrm{AM}$ the following morning, at which time the adult zebrafish were returned to their appropriate group tank. The fertilization process was repeated 3 times (1 time per week). Embryo medium, consisting of ultra-pure water, containing trace amounts of minerals and adjusted to $\mathrm{pH} 7.2$, was used to maintain the developing zebrafish embryos and was freshly prepared for each experiment according to Westerfield [31]. All zebrafish embryos were staged, anesthetized with MS222 and fixed in 4\% phosphate-buffered paraformaldehyde at 96 hours post fertilization (hpf) as described by Kimmel et al. [32].

All procedures for animal use were approved by the Texas A\&M University. Laboratory Animal Use Committee and all zebrafish were maintained and used according to protocols consistent with the Information Resources on Zebrafish, Animal Welfare Information Center Resource Series, No. 46, August, 2010, U.S.D.A. (http://www.nal.usda.gov/awic/pubs/Zebrafish2010.pdf), compiled by Scholfield [33].

\subsection{Morphological Assessment}

Zebrafish embryos (ZFEs) were periodically removed from the $28.5^{\circ} \mathrm{C}$ incubator and briefly examined at room temperature $\left(25^{\circ} \mathrm{C}\right)$ to monitor the developmental stage, mortality, hatching, response to touch (elicited movement) by hatched embryos, and the presence of any deformities at 24, 48, 72, and 96 hours post fertilization (hpf). At 96 hpf, ZFEs were anesthetized with MS-222 and fixed in 4\% phosphate-buffered paraformaldehyde (pH 7.4) for 12 hours at $4^{\circ} \mathrm{C}$, then stored in phosphate buffered saline (PBS) at $4^{\circ} \mathrm{C}$. ZFE morphology was assessed in the fixed state using a SZ-40 binocular microscope (Olympus, Center Valley, PA, USA). Images of embryos were captured using an Eclipse E400 microscope equipped with a 2× objective, a Nikon DXM1200 digital camera, and ACTI imaging software (Nikon Instruments, Melville, NY, USA). Using NIH Image J, the body length, eye area and yolk sac area were measured.

\subsection{Histological Analysis of Adult Fish Tissues}

At the end of the feeding experiment (5 weeks), the fish were anesthetized with MS-222 and then killed by chilling on wet ice. The brain, eyes, liver, segments of skeletal muscles and ovaries were dissected for DNA analysis. From the remaining body parts, skin/scales, nerve, spinal cord, medulla oblongata, blood vessels, red blood cells, gonads (male and females), small intestine, large intestine, cartilage, bones, gills, unilocular adipose tissue and skeletal muscles were fixed in $10 \%$ neutral buffered formalin (NB), processed for paraffin embedding, sectioned at $5 \mu \mathrm{m}$, and the sections placed on glass microscope slides, stained with $\mathrm{H} \& \mathrm{E}$ stain and cover slipped with Permount (VWR, Radnor, PA, USA). The investigator was blind as to the exposure of the individual zebrafish (control vs. GM) when all tissues were examined for the presence of any morphologic abnormalities. Two to 4 sections of each tissue from each zebrafish were assessed.

\subsection{Assessment of DNA Transfer}

\subsubsection{DNA Extraction}

A full set of tissues were collected including brain, eyes, liver and skeletal muscle from adult male zebrafish and brain, eyes, liver, skeletal muscle and ovaries from adult female zebrafish. All collected samples including adult 
zebrafish tissues and embryos were stored at $-70^{\circ} \mathrm{C}$ until the DNA was extracted.

DNA from zebrafish selected tissues and embryos was extracted using DNeasy Blood and Tissue kits (Qiagen GmbH, Hilden, Germany). DNA from transgenic corn (positive control) was extracted using the DNeasy Plant Mini kit (Qiagen GmbH, Hilden, Germany). DNA purity and concentration were determined using a Nano-Drop Spectrophotometer (Model 2000, Thermo Scientific, Wilmington, DE, USA).

\subsubsection{PCR Analysis}

DNA from transgenic corn MON89034 $\times$ MON88017 was used as a positive control for the presence of 35S promotor, NOS terminator, zein gene, Cry3Ab1, Cry1A105 and Cry2Ab2. Also, $\beta$-globin is a housekeeping gene of zebrafish was used as an internal control.

Two-step-down multiplex PCR (2SD-mPCR) was used to optimally amplify target segments of the 35S promotor, NOS terminator and zein gene (endogenous plant gene). Reactions were carried out in $25-\mu 1$ mixtures consisting of $12.5 \mu 12 \times$ GoTaq $^{\circledR}$ Green PCR Master (Promega, USA), $10.75 \mu 1$ DNase- and RNase-free water (Promega, USA), $1.25 \mu \mathrm{l} 10 \times$ primer mix (Table 1 ) containing $0.2 \mu \mathrm{M}$ of each primer, and $\sim 50 \mathrm{ng}$ of genomic DNA. PCR conditions included two steps: The first step consisted of 15 cycles of initial denaturation at $95^{\circ} \mathrm{C}$ for $15 \mathrm{~min}$, denaturation at $94^{\circ} \mathrm{C}$ for $30 \mathrm{~s}$, annealing at $62^{\circ} \mathrm{C}$ for $90 \mathrm{~s}$ and extension at $72^{\circ} \mathrm{C}$ for $90 \mathrm{~s}$. The second step consisted of 20 cycles of denaturation at $94^{\circ} \mathrm{C}$ for $30 \mathrm{~s}$, annealing at $57^{\circ} \mathrm{C}$ for $90 \mathrm{~s}$, extension at $72^{\circ} \mathrm{C}$ for $90 \mathrm{~s}$ and final extension at $72^{\circ} \mathrm{C}$ for $10 \mathrm{~min}$.

For event-specific primers, single plex PCR reactions were used. For Cry3Ab1, the reaction was carried out in $25-\mu l$ mixtures consisting of $12.5 \mu \mathrm{l} 2 \times$ GoTaq $^{\circledR}$ Green PCR Master (Promega, USA), $10.75 \mu$ DNase- and RNase-free water (Promega, USA), $1.25 \mu \mathrm{l}$ of $0.2 \mu \mathrm{M}$ primer (Table 1), and $\sim 50$ ng of genomic DNA. The PCR conditions consisted of the following: pre-incubation at $94^{\circ} \mathrm{C}$ for $5 \mathrm{~min}, 40$ cycles of denaturation at $94^{\circ} \mathrm{C}$ for 30 s, annealing at $61^{\circ} \mathrm{C}$ for $30 \mathrm{~s}$, extension at $72^{\circ} \mathrm{C}$ for $30 \mathrm{~s}$, and terminal elongation at $72^{\circ} \mathrm{C}$ for $8 \mathrm{~min}$. For both Cry1A105 and Cry2Ab2, the reactions were carried out in $25 \mu 1$ mixtures consisting of the following: $12.5 \mu 12 \times$ GoTaq ${ }^{\circledR}$ Green PCR Master (Promega, USA), $10.75 \mu \mathrm{l}$ of DNase- and RNase-free water (Promega, USA), 1.25 $\mu \mathrm{l}$ of $0.3 \mu \mathrm{M}$ primer (Table 1 ), and $\sim 50 \mathrm{ng}$ of genomic DNA. The PCR conditions were $2 \mathrm{~min}$ at $50^{\circ} \mathrm{C}$ for $5 \mathrm{~min}$, $10 \mathrm{~min}$ at $95^{\circ} \mathrm{C}, 45$ cycles of: $15 \mathrm{~s}$ at $95^{\circ} \mathrm{C}$ and $1 \mathrm{~min}$ at $60^{\circ} \mathrm{C}$. For $\beta$-globin, the reaction was carried out in $25-\mu 1$ mixtures consisting of the following: $12.5 \mu \mathrm{l} 2 \times \mathrm{GoTaq}^{\circledR}$ Green PCR Master (Promega, USA), $10.75 \mu 1$ DNaseand RNase-free water (Promega, USA), $1.25 \mu \mathrm{l}$ of $0.2 \mu \mathrm{M}$ primer (Table 1), and $\sim 50$ ng of genomic DNA. The

Table 1. List of primers used for PCR analyses.

\begin{tabular}{|c|c|c|c|}
\hline Target & Primer name & Sequence (5'-3') & Expected product size (bp) \\
\hline \multirow[t]{2}{*}{$\beta$-globin } & $\beta$-globin-F & AGGTGTCTCATCGTGTACCCCT & 230 \\
\hline & $\beta$-globin-R & CTTACCCTGAAGTTGTCGGGA & \\
\hline \multirow[t]{2}{*}{ MON88017 } & Cry3Bb1-F & CAGCAGAATCGTGTGACAAC & 120 \\
\hline & Cry3Bb1-R & TTTCCCGGACATGAAGCCAT & \\
\hline \multirow[t]{2}{*}{ MON89034 } & Cry1A.105-F & TCAGAGGTCCAGGGTTTACAGG & 133 \\
\hline & Cry1A.105-R & GTAGTAGAGGCATAGCGGATTCTTG & \\
\hline \multirow[t]{2}{*}{ MON89034 } & Cry2Ab2-F & AАTTCTAАCTACTTCCCCGACTACTTC & 121 \\
\hline & Cry2Ab2-R & ACGGAGAGGCGATGTTCCTG & \\
\hline \multirow[t]{2}{*}{$35 \mathrm{~S}$} & $35 \mathrm{~S}-\mathrm{F}$ & GACAGTGGTCCCAAAGATGGAC & 115 \\
\hline & $35 S-R$ & CCTTACGTCAGTGGAGATATC & \\
\hline \multirow[t]{2}{*}{ NOS } & NOS-F & CTGTTGCCGGTCTTGCGATG & 185 \\
\hline & NOS-R & GCGCGATAATTTATCCTAGTTTG & \\
\hline \multirow[t]{2}{*}{ Zein } & Zein-F & AGTGCGACCCATATTCCAG & 277 \\
\hline & Zein-R & GACATTGTGGCATCATCATTT & \\
\hline
\end{tabular}


PCR reaction conditions were 35 cycles at $94^{\circ} \mathrm{C}$ for $1 \mathrm{~min}, 55^{\circ} \mathrm{C}$ for 1 min and $72^{\circ} \mathrm{C}$ for $2 \mathrm{~min}$.

\subsection{Statistical Analysis}

Statistical analysis was carried out on all data collected using one-way ANOVA and Duncan New Multiple Range post hoc test from the SPSS 16.0 package. Mean values of the test groups with the controls groups were compared.

\section{Results and Discussion}

\subsection{Morphological Assessment}

Development is a critically sensitive period where changes in environmental conditions can alter the normal program of embryogenesis [34]. We are the first to have performed embryonic morphological assessments of zebrafish embryos (ZFEs) produced by adult fish fed GM corn compared to ZFEs from adult fed non-GM corn. No deformities were observed in the body length, eye area or yolk sac area of ZFEs produced by control zebrafish fed non-GM corn or in ZFEs produced by treated zebrafish fed GM corn. Also, as seen in Table 2 there were no significant differences between the two groups of embryos with respect to body length, eye area and yolk sac area measurements.

Survival was observed after 24, 48, 72, and 96 hours post fertilization (hpf) (Figure 1(a)). This was done by counting live/dead ZFEs/larvae for each group and the specified time points. The survival percentages tended to be slightly higher for the ZFEs treated-zebrafish fed GM corn than ZFEs control-zebrafish fed non-GM corn. However, these increases were only trends and not significantly different.

With regard to hatching, at $48 \mathrm{hpf} 31 \%$ of the control embryos had hatched from their chorions and an equal number (30\%) of the ZFEs produced by adult zebrafish fed GM corn (Figure 1(b)) also had hatched by 48 hpf. After $72 \mathrm{hpf}$ the hatching percentage was at 92\% in both control ZFEs and ZFEs produced by adult zebrafish fed GM corn. All ZFEs from control zebrafish adults as well as from adult zebrafish fed GM corn had after $96 \mathrm{hpf}$ exhibiting approximately $2 \%$ mortality. Sreedevi et al. [35] reported that hatching is a critical period of embryogenesis, and hatching has been used as an important assessment endpoint in the early stages of fish development.

Starting between 19 and 24 hpf, ZFEs began to show spontaneous motor movements of the body; the tail coiled rapidly followed by a slower relaxation phase [36] [37]. Control ZFEs and ZFEs produced from adult zebrafish fed GM corn exhibited normal spontaneous movements that were not significantly different (data not shown). However, there were significant differences between the two groups (Figure 1(c)) with respect to elicited movement, which was generated by touching the tail of hatched ZFEs at $96 \mathrm{hpf}$ with the tip of an insect pin. Significantly more ZFEs produced by adult zebrafish fed GM corn responded to being touched by the insect pin than ZFEs produced by adult zebrafish fed non-GM corn. However when the distance each ZFE moved was analyzed, ZFEs produced by adult zebrafish fed GM corn did not swim as great a distance in their response as did ZFEs produced by adult zebrafish fed non-GM corn. The reason for this difference is not clear. It is possible that the ZFEs produced by adult zebrafish fed GM corn were somewhat more advanced in their development compared to ZFEs produced by adult zebrafish fed non-GM corn. Additional behavioral studies are warranted to better understand this difference in response.

Table 2. Morphological measurements of ZFEs produced from zebrafish fed non-GM corn (Group I) and ZFEs produced from zebrafish fed GM corn (Group II).

\begin{tabular}{ccc}
\hline & & Groups \\
Measurement & & \\
& Group (I) & Group (II) \\
\hline Body length $(\mathrm{mm})$ & $3.46 \pm 0.11(\mathrm{n}=60)^{* *}$ & $3.47 \pm 0.14(\mathrm{n}=60)$ \\
Eye area $\left(\mathrm{mm}^{2}\right)$ & $0.068 \pm 0.007(\mathrm{n}=60)$ & $0.068 \pm 0.007(\mathrm{n}=58)$ \\
Yolk sac area $\left(\mathrm{mm}^{2}\right)$ & $0.126 \pm 0.021(\mathrm{n}=60)$ & $0.122 \pm 0.023(\mathrm{n}=58)$ \\
\hline
\end{tabular}

\footnotetext{
"There are no significant differences between the groups $(\mathrm{P}<0.05) .{ }^{* *}$ Results are mean \pm SD of three replicated independent experiments.
} 


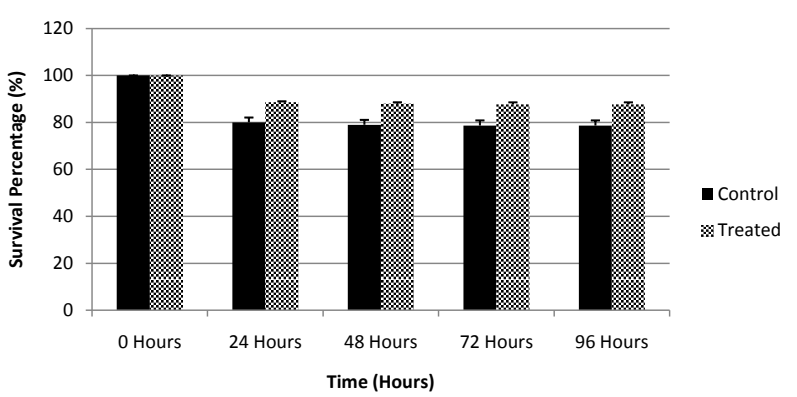

(a)

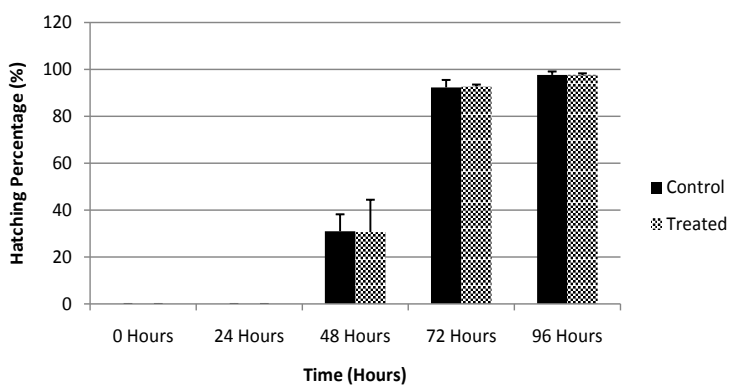

(b)

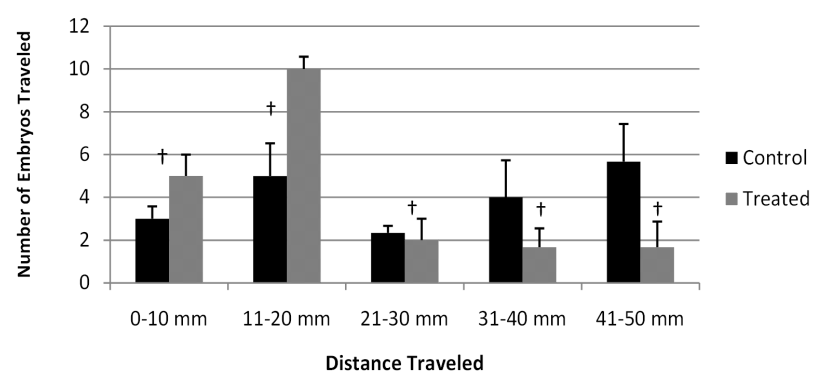

(c)

Figure 1. Survival percentage (a), hatching percentage (b) and elicited movements (c) of ZFEs produced from zebrafish fed non-GM corn and ZFEs produced from zebrafish fed GM corn. Data were averaged from triplicate experiments and are shown as the mean \pm SEM. ${ }^{\dagger}$ Indicates significant differences.

\subsection{Histological Analysis of Adult Fish Tissues}

No abnormalities or significant differences were observed for any of the tissues or organ that observed when adult control zebrafish fed non-GM corn were compared to adult treated-zebrafish that were fed GM corn.

\subsection{Assessment the Transgenic DNA Transfer}

\subsubsection{DNA Traceability}

Assessment of the presence of plant derived-DNA was conducted using PCR on various fish tissues, including: brain, eye, liver and skeletal muscle from male adult zebrafish and brain, eye, liver, skeletal muscle and ovaries from female adult zebrafish and also from 96 hpf ZFEs. Due to possible sampling of intestinal contents and obtaining plant material if the gastrointestinal (GI) tract was decided that there was additional risk with respect to contamination of the surrounding organs, so investigation of the GI tract was not performed [38]-[40]. Identification of DNA fragments in the intestinal wall might have been due to passage of nucleic acid into the fish tissues, but it is almost impossible to thoroughly clean the samples from intestinal contents and the risk of false positives due to contamination was too high [30] [40]. Therefore, we focused on investigating for the presence of plant DNA in the main organs that were sampled with extreme care to avoid contamination. Three independent DNA isolations were performed on each organ and tested with PCR for the presence of six target corn gene fragments (35S promoter, NOS terminator, Zein, Cry3Ab1, Cry1A105 and Cry2Ab2). Zein represents a maize multicopy gene [41], and is used as positive control to identify maize DNA (Tables 3-5). To eliminate the presence of inhibitors in PCR reactions, DNA quality was confirmed by amplification of a $230 \mathrm{bp}$ fragment of the $\beta$-globin as a housekeeping of zebrafish DNA preparations (Tables 3-5). Cry3Ab1, Cry1A105 and Cry2Ab2 are the synthetic single copy genes inserted into the maize event MON89034 $\times$ MON88017 [42].

PCR tests were performed in triplicate. The samples of each independent DNA isolation (two samples for each organ) were processed all together to reduce variability of yield and quality. To overcome the problem of DNA extraction from the small zebrafish embryos, 10 embryos were pooled per sample and the pooled samples were used for the extraction. The genes chosen for detection were selected in highlight differences in PCR amplification and tissue specificity. 
Table 3. Results of PCR reactions for the presence of CaMV 35S promoter, NOS terminator, specific genes- $\beta$-globin as housekeeping gene for zebrafish tissues, Cry1A.105 gene specific for GM corn MON89034, Cry2Ab2 gene specific for GM corn event MON89034 and Cry3Bb1 gene specific for GM corn event MON88017 in DNA sequences of Zebrafish male tissue samples.

\begin{tabular}{|c|c|c|c|c|c|c|c|c|c|c|c|c|c|c|}
\hline \multirow[b]{2}{*}{ Sample } & \multicolumn{7}{|c|}{ Group (I) ${ }^{*}$} & \multicolumn{7}{|c|}{ Group (III) ${ }^{*}$} \\
\hline & $\begin{array}{l}\text { 足 } \\
\sum_{0}^{\infty} \\
\sum_{j}\end{array}$ & $\begin{array}{l}\text { n } \\
\mathbf{z}\end{array}$ & 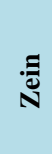 & 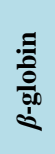 & 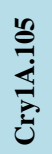 & సै & $\begin{array}{l}\overrightarrow{0} \\
\text { लै } \\
\text { है }\end{array}$ & 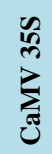 & ஜ & 芯 & 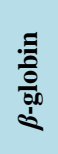 & 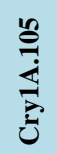 & 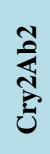 & 官 \\
\hline Negative control & - & - & - & - & - & - & - & - & - & - & - & - & - & - \\
\hline Positive control & + & + & + & - & + & + & + & + & + & + & - & + & + & + \\
\hline Eye & - & - & - & + & - & - & - & - & - & - & + & - & - & - \\
\hline Brain & - & - & - & + & - & - & - & - & - & - & + & - & - & - \\
\hline Muscles & - & - & - & + & - & - & - & - & - & - & + & - & - & - \\
\hline Liver & - & - & - & + & - & - & - & - & - & - & + & - & - & - \\
\hline
\end{tabular}

*Group (I): Male control group fed non-GM corn. Group (III): Male experimental group fed GM corn.

Table 4. Results of PCR reactions for the presence of CaMV 35S promoter, NOS terminator, specific genes- $\beta$-globin as housekeeping gene for zebrafish tissues, Cry1A.105 gene specific for GM corn MON89034, Cry2Ab2 gene specific for GM corn event MON89034 and Cry3Bb1 gene specific for GM corn event MON88017 in DNA sequences of Zebrafish female tissue samples.

\begin{tabular}{|c|c|c|c|c|c|c|c|c|c|c|c|c|c|c|}
\hline \multirow[b]{2}{*}{ Sample } & \multicolumn{7}{|c|}{ Group (II) ${ }^{*}$} & \multicolumn{7}{|c|}{ Group (IV) ${ }^{*}$} \\
\hline & 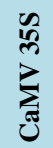 & $\begin{array}{l}\text { n } \\
\mathbf{z}\end{array}$ & 志 & 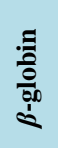 & 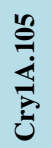 & 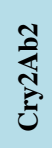 & $\begin{array}{l}\overrightarrow{0} \\
\text { है }\end{array}$ & $\sum_{0}^{\infty}$ & $\begin{array}{l}\text { D } \\
z\end{array}$ & 芯 & $\begin{array}{l}\text { 훙 } \\
\frac{0}{00} \\
0 \\
0\end{array}$ & 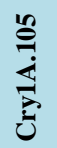 & 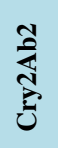 & 总 \\
\hline Negative control & - & - & - & - & - & - & - & - & - & - & - & - & - & - \\
\hline Positive control & + & + & + & - & + & + & + & + & + & + & - & + & + & + \\
\hline Eye & - & - & - & + & - & - & - & - & - & - & + & - & - & - \\
\hline Brain & - & - & - & + & - & - & - & - & - & - & + & - & - & - \\
\hline Muscles & - & - & - & + & - & - & - & - & - & - & + & - & - & - \\
\hline Liver & - & - & - & + & - & - & - & - & - & - & + & - & - & - \\
\hline Ovaries & - & - & - & + & - & - & - & - & - & - & + & - & - & - \\
\hline
\end{tabular}

*Group (II): Female control group fed non-GM corn. Group (IV): Female experimental group fed GM corn.

\subsubsection{Detection of Transgenic and Endogenous Plant DNA in Adult Male and Female Zebrafish}

Tissues

The DNA sequences of 35s CaMV and NOS terminator that is present in GM corn MON89034 $\times$ MON88017, and endogenous zein gene of corn, were not detected in any sample of adult male and female zebrafish tissues. The fragments of endogenous plant genes, zein (277 bp) and 35s CaMV (115 bp) and NOS terminator (185 bp) were present only in the samples extracted from GM corn, which used as positive controls (Table 3 and Table 4). All samples gave positive results for $\beta$-globin (230 bp) which is housekeeping gene found in zebrafish DNA, indicating the quality of extracted DNA was good (Table 3 and Table 4). Similarly, the sequences of transgenes Cry1A105 (133 bp) and Cry2Ab2 (121 bp) and Cry3Ab1 (120 bp) were present only in the samples extracted from GM corn, which were used as positive controls as well (Table 3 and Table 4).

Our results agreed with several published articles demonstrating the complete digestion of the transgenic 
Table 5. Results of PCR reactions for the presence of CaMV 35S promoter, NOS terminator, specific genes- $\beta$-globin as housekeeping gene for zebrafish tissues, Cry1A.105 gene specific for GM corn MON89034, Cry2Ab2 gene specific for GM corn event MON89034 and Cry3Bb1 gene specific for GM corn event MON88017 in DNA sequences of ZFEs tissue.

\begin{tabular}{|c|c|c|c|c|c|c|c|c|c|c|c|c|c|c|}
\hline \multirow[b]{2}{*}{ Sample } & \multicolumn{7}{|c|}{ Group (I) ${ }^{*}$} & \multicolumn{7}{|c|}{ Group (II)* } \\
\hline & $\sum_{0}^{\infty}$ & ô & $\stackrel{\Xi}{\stackrel{\Xi}{N}}$ & 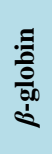 & 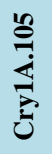 & 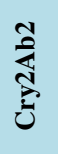 & $\begin{array}{l}\overrightarrow{0} \\
\text { लै } \\
\text { 己े }\end{array}$ & $\sum_{0}^{\infty}$ & $\begin{array}{l}\text { n } \\
\text { z }\end{array}$ & 芯 & 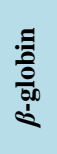 & 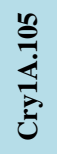 & 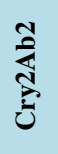 & $\begin{array}{l}\overrightarrow{0} \\
\text { है }\end{array}$ \\
\hline Negative control & - & - & - & - & - & - & - & - & - & - & - & - & - & - \\
\hline Positive control & + & + & + & - & + & + & + & + & + & + & - & + & + & + \\
\hline ZFEs, Group I & - & - & - & + & - & - & - & - & - & - & + & - & - & - \\
\hline ZFEs, Group II & - & - & - & + & - & - & - & - & - & - & + & - & - & - \\
\hline
\end{tabular}

*Group (I): ZFEs produced from fish fed non-GM corn. Group (II): ZFEs produced from fish fed GM corn.

DNA from plants that are consumed. Studies aiming at verifying the presence of transgenic fragments in organs and tissues from animals that consumed GM plants, also gave negative results. In the study of Sissener et al. [30], fragments of transgene from MON 810 corn were detected only in intestinal organs and in one liver sample of zebrafish fed diet containing GM corn and the authors attributed that finding to the presence of residual feed in the intestine and contamination of one liver sample from the intestinal organs during sampling [30]. Świątkiewicz et al. [43] detected relatively small fragments of single-copy RR and $B t$ transgenes in all samples of crop and gizzard content, but the transgenes were not detected in any samples of duodenum, jejunum, ileum, and caecum digesta, excreta, and tissues (blood, liver, spleen, breast muscle) of chickens fed GM soybean meal and corn. Furthermore, Świątkiewicz et al. [43] found that the DNA sequences of 35s CaMV that were present in RR soybean and Bt corn, NOS terminator of RR soybean, and endogenous lectin and invertase genes of soybean and corn, were not detected in any sample of excreta and tissues. Also, transgenic DNA was not detectable in tissues of pigs or rabbits fed diets containing GM corn [44] [45] or soybean meal [23] [46]. Walsh et al. [8] stated that no transgenic or corn-specific DNA could be detected in the tissues of pigs (including heart, liver, spleen, kidney, and muscle) fed a GM corn-based diet. No transgenic or corn-specific DNA was detected in any tissue samples of hen (such as breast muscle, leg muscle, ovary, oviduct, and eggs) from the non-GM-fed and GM-fed groups. These data suggest that no corn-endogenous genes or transgenic fragments had been transferred to the hens' tissues [47].

Netherwood et al. [39] found that small proportions of transgenic genes in GM soya, such as the native soya DNA, survives passage through the human upper gastrointestinal tract but is completely degraded by the time it reaches the large intestine. Although they found some evidence of preexisting gene transfer between GM soya and the human small intestinal microflora, the bacteria containing the transgene represented a very small proportion of total microbial population, and there was no indication that the complete transgene had been transferred to the prokaryotes. Thus, it is highly unlikely that the gene transfer events seen in the study by Netherwood et al. [39] would alter gastrointestinal function or pose a risk to human health.

\subsubsection{Detection of Transgenic and Endogenous Plant DNA in Zebrafish Embryos}

It was important to assess the possibility of DNA transfer to embryos when adult zebrafish were fed GM ingredients. As was observed for the adult zebrafish organs and tissues, the DNA sequences of 35s CaMV, NOS terminator, Cry1A105, Cry2Ab2 and Cry3Ab1 that are present in GM corn MON89034 × MON88017, and endogenous zein gene of corn, were not detected in any sample of zebrafish embryos (Table 5).

In a study carried out by Prescott et al. [48] embryos of GM soy-fed adult mice also showed temporary changes in their DNA function, compared to those whose parents were fed non-GM soy. Tudisco et al. [49] found in goat study that transgenic target DNA sequences (35S and CP4 EPSPS) were not detected in organs from control kids whose dams received a diet containing conventional soybean meal. In contrast, transgenic DNA fragments were amplified from some samples of kids whose dams received transgenic soybean. Also, the CP4 EPSPS fragment was found in more samples compared with the 35S fragment. The author mentioned that 
the reason for such a result is not clear, but it could be due to slight differences in PCR conditions.

To the best of our knowledge, this is the first study to assess the possibility of transgenic DNA transfer to ZFEs produced by adult zebrafish fed on GM corn.

\section{Conclusion}

The present study showed that no abnormalities were observed in embryonic morphology of ZFEs that were produced from adult zebrafish fed GM-corn in their diet. In addition neither the plant DNA reference gene nor transgenic DNA were found in tissue samples of the adult male and female zebrafish fed genetically modified corn and the same negative observation was made for the ZFEs produced by the adult fish that were fed the GM corn. According to our previously study [16], which proved that GM corn MON89034 × MON88017 is substantially equivalent to its conventional counterpart and the results from the current study, it can be concluded that corn event MON89034 $\times$ MON88017 is as safe and nutritious as non-GM corn.

\section{Acknowledgements}

The authors are grateful to Dr. Gary N. Odvody, Texas Agrilife Research and Extension Center for supplying us with the samples of GM corn. We also thank Prof. Dr. James Derr, Texas A\&M University for providing us with the laboratory space to carry out the PCR experiments.

\section{References}

[1] Shin, K., Suh, S., Lim, M., Woo, H., Lee, J.H., Kim, H. and Cho, H. (2013) Event-Specific Detection System of Stacked Genetically Modified Maize by Using the Multiplex-PCR Technique. Food Science and Biotechnology, 22, 1763-1772. http://dx.doi.org/10.1007/s10068-013-0278-3

[2] Halpin, C. (2005) Gene Stacking in Transgenic Plants the Challenge for $21^{\text {st }}$ Century Plant Biotechnology. Plant Biotechnology Journal, 3, 141-155. http://dx.doi.org/10.1111/j.1467-7652.2004.00113.x

[3] European Food Safety Authority (2011) EFSA Panel on Genetically Modified Organisms (GMO); Scientific Opinion on Guidance for Risk Assessment of Food and Feed from Genetically Modified Plants. EFSA Journal, 9, 2150.

[4] European Commission (2013) Commission Implementation Regulation (EU) 503/2013 on Applications for Authorization of Genetically Modified Food and Feed in Accordance with Regulation (EC) 1829/2003. Official Journal of European Union, L157/1.

[5] MacCormick, C.A., Griffin, H.G., Underwood, H.M. and Gasson, M.J. (1998) Common DNA Sequences with Potential for Detection of Genetically Manipulated Organisms in Food. Journal of Applied Microbiology, 84, 969-980. http://dx.doi.org/10.1046/j.1365-2672.1998.00429.x

[6] Ran, T., Mei, L., Lei, W., Aihua, L., Ru, H. and Jie, S. (2009) Detection of Transgenic DNA in Tilapias (Oreochromis niloticus, GIFT Strain) Fed Genetically Modified Soybeans (Roundup Ready). Aquaculture Research, 4, 1350-1357. http://dx.doi.org/10.1111/j.1365-2109.2009.02187.x

[7] Finamore, A., Roselli, M., Britti, S., Monastra, G. and Ambra, R. (2008) Intestinal and Peripheral Immune Response to MON810 Maize Ingestion in Weaning and Old Mice. Journal of Agriculture and Food Chemistry, 56, 11533-11539. http://dx.doi.org/10.1021/jf802059w

[8] Walsh, M.C., Buzoianu, S.G., Gardiner, G.E., Rea, M.C. and Gelencser, E. (2011) Fate of Transgenic DNA from Orally Administered Bt MON810 Maize and Effects on Immune Response and Growth in Pigs. PLoS ONE, 6, e27177. http://dx.doi.org/10.1371/journal.pone.0027177

[9] Walsh, M.C., Buzoianu, S.G., Gardiner, G.E., Rea, M.C. and Ross, R.P. (2012) Effects of Short-Term Feeding of Bt MON810 Maize on Growth Performance, Organ Morphology and Function in Pigs. British Journal of Nutrition, 107, 364-371. http://dx.doi.org/10.1017/S0007114511003011

[10] Buzoianu, S.G., Walsh, M.C., Rea, M.C., O’Sullivan, O. and Crispie, F. (2012) The Effect of Feeding Bt MON810 Maize to Pigs for 110 Days on Intestinal Microbiota. PLoS ONE, 7, e33668. http://dx.doi.org/10.1371/journal.pone.0033668

[11] Ma, Q.G., Gao, C.Q., Zhang, J.Y., Zhao, L.H., Hao, W.B. and Ji, C. (2013) Detection of Transgenic and Endogenous Plant DNA Fragments and Proteins in the Digesta, Blood, Tissues, and Eggs of Laying Hens Fed with Phytase Transgenic Corn. PLoS ONE, 8, e61138. http://dx.doi.org/10.1371/journal.pone.0061138

[12] Herman, R.A., Storer, N.P., Phillips, A.M., Prochaska, L.M. and Windels, P. (2007) Compositional Assessment of Event DAS-59122-7 Maize Using Substantial Equivalence. Regulatory Toxicology and Pharmacology, 47, 37-47. http://dx.doi.org/10.1016/j.yrtph.2006.08.007 
[13] Li, X., He, X.Y., Luo, Y.B., Xiao, G.Y., Jiang, X.B. and Huang, K.L. (2008) Comparative Analysis of Nutritional Composition between Herbicide-Tolerant Rice with Bar Gene and Its Non-Transgenic Counterpart. Journal of Food Composition and Analysis, 21, 535-539. http://dx.doi.org/10.1016/j.jfca.2008.06.001

[14] Wang, Y., Xu, W.T., Zhao, W.W., Hao, J.R., Luo, Y.B., Tang, X.G., Zhang, Y. and Huang, K.L. (2012) Comparative Analysis of the Proteomic and Nutritional Composition of Transgenic Rice Seeds with Cry1ab/ac Genes and Their Non-Transgenic Counterparts. Journal of Cereal Science, 55, 226-233. http://dx.doi.org/10.1016/j.jcs.2011.12.004

[15] Gayen, D., Sarkar, S.N., Datta, S.K. and Datta, K. (2013) Comparative Analysis of Nutritional Compositions of Transgenic High Iron Rice with Its Non-Transgenic Counterpart. Food Chemistry, 138, 835-840. http://dx.doi.org/10.1016/j.foodchem.2012.11.065

[16] Rayan, A.M. and Abbott, L.C. (2015) Compositional Analysis of Genetically Modified Corn Events (NK603, MON88017 × MON810 and MON89034 × MON88017) Compared to Conventional Corn. Food Chemistry, 176, 99105. http://dx.doi.org/10.1016/j.foodchem.2014.12.044

[17] Shimada, N., Murata, H., Mikami, O., Yoshioka, M. and Guruge, K.S. (2006) Effects of Feeding Calves Genetically Modified Corn Bt11: A Clinico-Biochemical Study. Journal of Veterinary Medical Science, 68, 1113-1115. http://dx.doi.org/10.1292/jvms.68.1113

[18] Sanden, M., Krogdahl, A., Bakke-McKellep, A.M., Buddington, R.K. and Hemre, G.I. (2006) Growth Performance and Organ Development in Atlantic Salmon, Salmo salar L. Parr Fed Genetically Modified (GM) Soybean and Maize. Aquaculture Nutrition, 12, 1-14. http://dx.doi.org/10.1111/j.1365-2095.2006.00367.x

[19] Flachowsky, G., Aulrich, K., Bohme, H. and Halle, I. (2007) Studies on Feeds from Genetically Modified Plants (GMP)—Contributions to Nutritional and Safety Assessment. Animal Feed Science and Technology, 133, 2-30. http://dx.doi.org/10.1016/j.anifeedsci.2006.08.002

[20] Trabalza-Marinucci, M., Brandi, G., Rondini, C., Avellini, L. and Giammarini, C. (2008) A Three-Year Longitudinal Study on the Effects of a Diet Containing Genetically Modified Bt176 Maize on the Health Status and Performance of Sheep. Livestock Science, 13, 178-190. http://dx.doi.org/10.1016/j.livsci.2007.03.009

[21] Malatesta, M., Caporaloni, C., Rossi, L., Battistelli, S., Rocchi, M. and Tonucci, F. (2003) Ultrastructural Analysis of Pancreatic Acinar Cells from Mice Fed on Genetically Modified Soybean. Journal of Anatomy, 201, 409-415. http://dx.doi.org/10.1046/j.0021-8782.2002.00103.x

[22] Malatesta, M., Tiberi, C., Baldelli, B., Battistelli, S., Manuali, E. and Biggiogera, M. (2005) Reversibility of Hepatocyte Nuclear Modificationsin Mice Fed on Genetically Modified Soybean. European Journal of Histochemistry, 49, 237-242.

[23] Tudisco, R., Lombardi, P., Bovera, F., d’Angelo, D., Cutrignelli, M.I., Mastellone, V., Terzi, V., Avallone, L. and Infascelli, F. (2006) Genetically Modified Soya Bean in Rabbit Feeding: Detection of DNA Fragments and Evaluation of Metabolic Effects by Enzymatic Analysis. Animal Science, 82, 193-199. http://dx.doi.org/10.1079/ASC200530

[24] Ermakova, I. (2007) Experimental Evidence of GMO Hazards. Presentation at Scientists for a GM Free Europe, EU Parliament, Brussels.

[25] Séralini, G.E., Cellier, D. and Spiroux, J. (2007) New Analysis of a Rat Feeding Study with a Genetically Modified Maize Reveals Signs of Hepatorenal Toxicity. Archives Environmental Contamination Toxicology, 52, 596-602. http://dx.doi.org/10.1007/s00244-006-0149-5

[26] El-Shamei, Z.S., Gab-Alla, A.A., Shatta, A.A., Moussa, E.A. and Rayan, A.M. (2012) Histopathological Changes in Some Organs of Male Rats Fed on Genetically Modified Corn (Ajeeb YG). Journal of American Science, 8, 684-696.

[27] Jany, K.D. (2013) Critical Remarks on the Long-Term Feeding Study by Seralini et al. (2012). European Food and Feed Law Review, 3, 176-186.

[28] Appenzeller, L.M., Malley, L., MacKenzie, S.A., Hoban, D. and Delaney, B. (2009) Subchronic Feeding Study with Genetically Modified Stacked Trait Lepidopteran and Coleopteran Resistant (DAS-Ø15Ø7-1×DAS-59122-7) Maize Grain in Sprague-Dawley Rats. Food and Chemical Toxicology, 47, 1512-1520. http://dx.doi.org/10.1016/j.fct.2009.03.041

[29] Carvalho, A.P., Araujo, L. and Santos, M.M. (2006) Rearing Zebrafish (Danio rerio) Larvae without Live Food: Evaluation of a Commercial, a Practical and a Purified Starter Diet on Larval Performance. Aquaculture Research, 37, 1107-1111. http://dx.doi.org/10.1111/j.1365-2109.2006.01534.x

[30] Sissener, N.H., Johannessen, L.E., Hevrøy, E.M., Wiik-Nielsen, C.R., Berdal, K.G., Nordgreen, A. and Hemre, G.I. (2010) Zebrafish (Danio rerio) as a Model for Investigating the Safety of GM Feed Ingredients (Soya and Maize); Performance, Stress Response and Uptake of Dietary DNA Sequences. British Journal of Nutrition, 103, 3-15. http://dx.doi.org/10.1017/S0007114509991401

[31] Westerfield, M. (2000) The Zebrafish Book. A Guide for the Laboratory Use of Zebrafish (Danio rerio). 4th Edition, University of Oregon Press, Eugene. 
[32] Kimmel, C.B., Ballard, W.W., Kimmel, S.R., Ullmann, B. and Schilling, T.F. (1995) Stages of Embryonic Development of the Zebrafish. Developmental Dynamics, 203, 253-310. http://dx.doi.org/10.1002/aja.1002030302

[33] Scholfield, D. (2010) Information Resources on Zebrafish. AWIC Resource Series No. 46. USDA. http://www.nal.usda.gov/awic/pubs/Zebrafish2010.pdf

[34] Gilbert, S.F. (2001) Ecological Developmental Biology: Developmental Biology Meets the Real World. Developmental Biology, 233, 1-12. http://dx.doi.org/10.1006/dbio.2001.0210

[35] Sreedevi, B., Suvarchala, G. and Philip, G.H. (2014) Morphological and Physiological Abnormalities during Development in Zebrafish Due to Chlorpyrifos. Indian Journal of Science Research, 5, 1-8.

[36] Saint-Amant, L. and Drapeau, P. (1998) Time Course of the Development of Motor Behaviors in the Zebrafish Embryo. Journal of Neurobiology, 37, 622-632. http://dx.doi.org/10.1002/(SICI)1097-4695(199812)37:4<622::AID-NEU10>3.0.CO;2-S

[37] Drapeau, P., Saint-Amant, L., Buss, R.R., Chong, M., McDearmid, J.R. and Brustein, E. (2002) Development of the Locomotor Network in Zebrafish. Progress in Neurobiology, 68, 85-111. http://dx.doi.org/10.1016/S0301-0082(02)00075-8

[38] Duggan, P.S., Chambers, P.A., Heritage, J. and Forbes, J.M. (2003) Fate of Genetically Modified Maize DNA in the Oral Cavity and in Rumen of Sheep. British Journal of Nutrition, 89, 159-166. http://dx.doi.org/10.1079/BJN2002764

[39] Netherwood, T., Martin-Orúe, S.M., O’Donnel, A.G., Gockling, S., Graham, J. and Mathers, J.C. (2004) Assessing the Survival of Transgenic Plant DNA in the Human Gastrointestinal Tract. Nature Biotechnology, 22, 204-209. http://dx.doi.org/10.1038/nbt934

[40] Mazza, R., Soave, M., Morlacchini, M., Piva, G. and Marocco, A. (2005) Assessing the Transfer of Genetically Modified DNA from Feed to Animal Tissues. Transgenic Research, 14, 775-784. http://dx.doi.org/10.1007/s11248-005-0009-5

[41] Woo, Y.M., Hu, D.W.N., Larkins, B.A. and Jung, R. (2001) Genomics Analysis of Genes Expressed in Maize Endosperm Identifies Novel Seed Proteins and Clarifies Patterns of Zein Gene Expression. Plant Cell, 13, 2297-2317. http://dx.doi.org/10.1105/tpc.13.10.2297

[42] European Food Safety Authority (2010) Scientific Opinion on Application (EFSA-GMO-NL-2007-39) for the Placing on the Market of Insect Resistant and Herbicide Tolerant Genetically Modified Maize MON89034 x MON88017 for Food and Feed Uses, Import and Processing under Regulation (EC) No 1829/2003 from Monsanto. EFSA Journal, 8, 1564.

[43] Świątkiewicz, S., Twardowska, M., Markowski, J., Mazur, M., Sieradzki, Z. and Kwiatek, K. (2010) Fate of Transgenic DNA from Bt Corn and Roundup Ready Soybean Meal in Broilers Fed GMO Feed. Bulletin of the Veterinary Institute in Pulawy, 54, 237-242.

[44] Klotz, A., Mayer, J. and Einspanier, R. (2002) Degradation and Possible Carry Over of Feed DNA Monitored in Pigs and Poultry. European Food Research and Technology, 214, 271-275. http://dx.doi.org/10.1007/s00217-001-0444-3

[45] Reuter, T. and Aulrich, K. (2003) Investigations on Genetically Modified Maize (Bt-Maize) in Pig Nutrition: Fate of Feed-Ingested Foreign DNA in Pig Bodies. European Food Research and Technology, 216, 185-192.

[46] Jennings, J.C., Kolwyck, D.C., Kays, S.B., Whetsell, A.J., Surber, J.B., Cromwell, G.L., Lirette, R.P. and Genn, K.C. (2003) Determining Whether Transgenic and Endogenous Plant DNA and Transgenic Protein Are Detectable in Muscle from Swine Fed Roundup Ready Soybean Meal. Journal of Animal Science, 81, 1447-1455.

[47] Gao, C.Q., Ma, Q.G., Zhao, L.H., Zhang, J.Y. and Ji, C. (2014) Effect of Dietary Phytase Transgenic Corn on Physiological Characteristics and the Fate of Recombinant Plant DNA in Laying Hens. Asian-Australasian Journal of Animal Science, 27, 77-82. http://dx.doi.org/10.5713/ajas.2013.13265

[48] Prescott, V.E., Campbell, P.M. and Moore, A. (2005) Transgenic Expression of Bean $\alpha$-Amylase Inhibitor in Peas Results in Altered Structure and Immunogenicity. Journal of Agriculture and Food Chemistry, 53, 176-188. http://dx.doi.org/10.1021/jf050594v

[49] Tudisco, R., Mastellone, V., Cutrignelli, M.I., Lombardi, P., Bovera, F., Mirabella, N., Piccolo, G., Calabro, S., Avallone, L. and Infascelli, F. (2010) Fate of Transgenic DNA and Evaluation of Metabolic Effects in Goats Fed Genetically Modified Soybean and in Their Offsprings. Animal, 4, 1662-1671. http://dx.doi.org/10.1017/s1751731110000728 